\title{
Fallopian Tube Cancer pT3a TNM Finding v7
}

National Cancer Institute

\section{Source}

National Cancer Institute. Fallopian Tube Cancer pT3a TNM Finding v7. NCI Thesaurus. Code C89679.

Fallopian tube cancer with microscopic peritoneal metastasis outside the pelvis. (from AJCC 7th Ed.) 